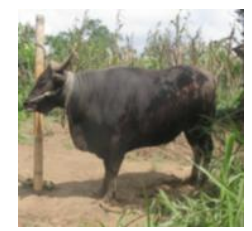

Jurmal FADET UNUD

\title{
PENGARUH PEMBERIAN RANSUM KOMERSIAL DITAMBAH TEPUNG KULIT KERANG SEBAGAI SUMBER KALSIUM TERHADAP PRODUKSI TELUR AYAM ISA BROWN UMUR 95 MINGGU
}

\author{
Rusnadi, I.N.S., G.A.M.K.Dewi dan A.T.Umiarti \\ PS Sarjana Peternakan, Fakultas Peternakan, Universitas Udayana, Denpasar, Bali \\ , Email : suarrusnadi@student.unud.ac.id, Telpon : +6282144932675
}

\begin{abstract}
ABSTRAK
Penelitian ini bertujuan untuk meningkatkan produksi telur ayam Isa Brown umur 95 minggu yang diberi ransum komersial ditambah tepung kulit kerang sebagai sumber kalsium. Penelitian dilaksanakan di Desa Pesedahan, Kecamatan Manggis, Kabupaten Karangasem selama 4 minggu. Materi penelitian yang digunakan ayam petelur Isa Brown umur 95 minggu. Rancangan penelitian yang digunakan Rancangan Acak Lengkap (RAL) yang terdiri dari 4 perlakuan yaitu ransum komersial tanpa tambahan tepung kulit kerang kalsium sebagai kontrol (A), ransum komersial ditambah1\% tepung kulit kerang (B), ransum komersial ditambah 2\% tepung kulit kerang (C), dan ransum komersial ditambah 3\% tepung kulit kerang (D), masing-masing perlakuan diulang sebanyak 5 ulangan setiap ulangan terdiri dari 5 ekor ayam. Variabel yang diamati adalah konsumsi ransum, produksi telur harian (hend day production), bobot telur, dan FCR. Hasil penelitian yang diperoleh setelah pemberian perlakuan ransum komersial ditambahkan 1\%, 2\%, dan 3\% tepung kulit kerang dapat meningkatkan bobot telur yang memperoleh rataan masing-masing sebesar 0,44\%, 0,49\%, $0,78 \%$ nyata lebih tinggi secara statistik berbeda nyata $(\mathrm{P}<0,05)$ dibandingkan dengan perlakuan A, sedangkan semua perlakuan secara statistik tidak berpengaruh terhadap variabel konsumsi ransum, produksi telur harian (hand day production), dan FCR. Berdasarkan hasil penelitian ini dapat disimpulkan bahwa pemberian ransum komersial dengan penambahan $2 \%$, dan 3\% tepung kulit kerang dapat meningkatkan bobot telur tetapi tidak memberikan hasil yang diharapkan terhadap produksi telur harian (hen day production), konsumsi ransum dan FCR dari ayam Isa Brown umur 95 minggu.
\end{abstract}

Kata kunci : tepung kulit kerang, Isa Brown, produksi telur, ransum komersial 


\title{
THE INFLUENCE OF COMMERCIAL RANSUM PLUS OYSTER SHELL AS A CALCIUM SOURCE ON PRODUCTION OF CHICKEN EGGS OF ISA BROWN AGE 95 WEEKS
}

\begin{abstract}
This study aims to increase the production of 95-week-old Isa Brown chicken eggs fed commercial rations plus oyster shell as a calcium. The study was conducted in Pesedahan Village, Manggis District, Karangasem Regency for 4 weeks. The research material used was Isa Brown laying hens aged 95 weeks. The research design used was a Completely Randomized Design (CRD) consisting of 4 treatments, namely commercial ration without the addition of calcium oyster shell as a control (A), commercial ration plus $1 \%$ oyster shell (B), commercial ration plus $2 \%$ clam oyster shell ( C), and commercial ration plus $3 \%$ of oyster shell (D), each treatment was repeated in 5 replications each repetition consisting of 5 chickens. The observed variables were ration consumption, daily egg production (hend day production), egg weight, and FCR. The results obtained after the administration of commercial ration treatment added $1 \%, 2 \%$, and $3 \%$ of oyster shell can increase the weight of eggs that obtain an average of each of $0.44 \%, 0.49 \%, 0.78 \%$ significantly higher statistically significantly different $(\mathrm{P}<0.05)$ compared to treatment $\mathrm{A}$, while all treatments did not statistically affect the ration consumption variable, daily egg production (hand day production), and FCR. Based on the results of this study it can be concluded that the provision of commercial rations with the addition of $2 \%$, and $3 \%$ shells flour can increase egg weight but do not give the expected results on daily egg production (hen day production), ration consumption and FCR of aged Isa Brown chickens 95 weeks.
\end{abstract}

Keywords : seashell flour, Isa Brown, egg production, commercial ration

\section{PENDAHULUAN}

Seiring dengan meningkatnya daya beli dan pemahaman masyarakat akan arti penting pemenuhan gizi khususnya yang bersumber dari hewani, menyebabkan meningkatnya permintaan akan produk peternakan. Hal ini mendorong pesatnya perkembangan sektor peternakan khususnya pada bidang perunggasan. Industri perunggasan di Indonesia secara umum didominasi oleh peternakan ayam ras pedaging dan petelur yang pengelolaannya dilakukan secara intensif.

Ayam petelur merupakan salah satu ternak unggas yang cukup potensial di Indonesia. Ayam petelur dibudidayakan khusus untuk menghasilkan telur secara komersial. Saat ini terdapat 2 kelompok ayam petelur yaitu tipe ayam medium dan tipe ringan. Tipe medium umumnya bertelur dengan kerabang coklat sedangkan tipe ringan bertelur dengan kerabang putih (North dan Bell, 1990). 
Menurut Bumi Merdeka (2010), ayam ras petelur strain ISA Brown ialah jenis ayam hibrida unggulan hasil persilangan dari ayam jenis "Rhode Island Red dan White Leghorns", yang diciptakan di Inggris pada tahun 1978 oleh perusahaan breeder ISA. Ciri khasnya adalah bulu dan telurnya berwarna cokelat. Ayam ISA Brown memiliki empat fase pertumbuhan, yaitu starter (umur 0-4 minggu), grower (umur 5-10 minggu), developer (umur 11-16 minggu) dan layer (umur >16 minggu). Periode produksi telur ayam ISA Brown dimulai dari minggu ke 18 sampai 90 yang produksinya mulai menurun.

Tepung kulit kerang merupakan salah satu bahan pakan yang merupakan sumber kalsium. Selain sebagai sumber kalsium, tepung kulit kerang juga berfungsi sebagai grit yang memiliki peranan penting dalam proses pencernaan ayam. Dalam saluran pencernaan ayam, grit akan mengoptimalkan kerja gizzard (ventrikulus) dalam memecah ransum sehingga nutrisi dapat terserap optimal sehingga produktivitas meningkat.

Kalsium memiliki peranan yang penting dalam pembentukan dan peningkatan produksi telur. Fungsi utama kalsium adalah untuk pembentukan tulang, kerabang telur, pembentukan darah serta pengatur sistem jaringan tubuh yang lain seperti hati, otot dan syaraf (Highfill, 1998). Setiap proses bertelur, ayam membutuhkan kalsium sebanyak 4 gram setiap hari (Wahju, 2004). Kebutuhan kalsium tersebut sebagian besar berasal dari kalsium pakan (60-75 \%) dan sisanya didapatkan dari kalsium tubuh (Farmer et al., 1983). Dewi (2010) menyatakan penambahan persentase kalsium dalam ransum ayam, akan menghasilkan telur dengan bobot lebih tinggi. Semua strain ayam petelur mengalami peningkatan bobot telur perbutir pada umur 26-50 minggu.

Penambahkan tepung kulit kerang pada ransum ayam ISA Brown umur 95 minggu yang produksinya mulai menurun, diharapkan bisa membantu mengoptimalkan proses pencernaan dan sekaligus sebagai sumber kalsium sehingga produksi telur pada umur tersebut masih produktif.

\section{MATERI DAN METODE}

\section{Tempat dan waktu penelitian}

Penelitian ini dilaksanakan di kandang ayam petelur yang berlokasi di Desa Pesedahan, Manggis, Karangasem, Bali. Penelitian dilaksanakan selama 4 minggu dari tanggal 1 - 29 Desember 2019. 


\section{Ayam}

Ayam yang digunakan dalam penelitian ini adalah ayam ISA Brown berumur 95 minggu yang berjumlah 100 ekor. Ayam ISA Brown tersebut diperoleh dari Farm Kembang Sari, Desa Pesedahan, Manggis, Karangasem, Bali.

\section{Kandang dan perlengkapan}

Kandang yang digunakan dalam penelitian ini adalah kandang battery, tiap petak kandang berukuran panjang $30 \mathrm{~cm}$, lebar $20 \mathrm{~cm}$, dan tinggi $30 \mathrm{~cm}$ yang terbuat dari kawat besi. Setiap 1 petak kandang diisi dengan 1 ekor ayam. Atap kandang menggunakan spandex dan alas kandang menggunakan papan. Kandang dilengkapi dengan tempat pakan menggunakan pipa paralon dan tempat air minum menggunakan nipple. Setiap petak kandang diberi label sesuai dengan perlakuan.

\section{Alat penelitian}

a. Timbangan digital

Penelitian ini menggunakan timbangan elektrik kapasitas $7 \mathrm{~kg}$ dengan tingkat kepekaan $1 \mathrm{~g}$ untuk menimbang telur dan ransum.

b. Egg tray

Penelitian ini menggunakan egg tray dengan bahan karton yang berkapasitas 30 butir. Egg tray digunakan untuk menaruh telur ayam yang telah diambil dari dalam kandang sesuai dengan perlakuan.

c. Alat tulis

Alat tulis yang digunakan untuk mencatat semua data yang diperoleh selama penelitian.

\section{Tepung kulit kerang}

Penelitian ini menggunakan tambahan kalsium yang bersumber dari kulit kerang. Kalsium tepung kulit kerang tersebut diperoleh dari Kembang Sari PS.

\section{Pakan yang digunakan}

Pakan yang digunakan dalam penelitian ini yaitu pakan komersial dari PT. Wonokoyo jenis KLS Super Plus. Adapun jumlah pakan komersial dan tambahan tepung kulit kerang dan kandungan nutrisi Ransum yang digunakan dalam penelitian dapat dilihat pada tabel dibawah. 
Tabel 1. Ransum Komersial Ayam Petelur

\begin{tabular}{lcccc}
\hline Ransum & \multicolumn{3}{c}{ Perlakuan } \\
\cline { 2 - 5 } & A & B & C & D \\
\hline Komersial & 100 & 100 & 100 & 100 \\
Tepung kulit kerang (\%) & 0 & 1 & 2 & 3 \\
\hline Total & 100 & 101 & 102 & 103 \\
\hline
\end{tabular}

Keterangan. Ransum PT. Wonokoyo( KLS Super Plus).

Tabel 2. Kandungan Nutrisi Ransum Penelitian

\begin{tabular}{lccccc} 
Kandungan Nutrien & \multicolumn{3}{c}{ Perlakuan ${ }^{1)}$} \\
\cline { 2 - 6 } & $\mathrm{A}^{2)}$ & $\mathrm{B}$ & $\mathrm{C}$ & $\mathrm{D}$ & Standar $^{3)}$ \\
\hline Energi Termetabolis Kkal/Kg & 2900 & 2871 & 2842 & 2813 & 2900 \\
Protein Kasar (\%) & 18 & 18 & 18 & 18 & $15-18$ \\
Lemak Kasar (\%) & 10,13 & 10,13 & 10,13 & 10,13 & $2,5-7,0$ \\
Serat Kasar (\%) & 3,08 & 3,08 & 3,08 & 3,08 & 7,0 \\
Kalsium/Ca (\%) & 3,13 & 3,47 & 3,81 & 4,15 & $3,25-4,0$ \\
Posfor/P (\%) & 0,45 & 0,46 & 0,47 & 0,48 & $0,6-0,9$
\end{tabular}

Keterangan :

1. A : Ransum komersial tanpa tambahan tepung kulit kerang

$\mathrm{B}$ : Ransum komersial dan $1 \%$ tepung kulit kerang

$\mathrm{C}$ : Ransum komersial dan $2 \%$ tepung kulit kerang

D : Ransum komersial dan 3\% tepung kulit kerang

2. Ransum komersial PT.Wonokoyo

3. Standar Pakan SNI (Standar Nasional Indonesia)

\section{Rancangan penelitian}

Penelitian ini menggunakan Rancangan Acak Lengkap (RAL) yang terdiri dari 4 perlakuan dan 5 ulangan. Setiap ulangan terdiri dari 5 ekor ayam, sehingga total ayam yang digunakan dalam penelitian ini sebanyak 100 ekor. Adapun perlakuan yang digunakan dalam penelitian ini yaitu: A : Ransum komersial tanpa tambahan tepung kulit kerang. B : Ransum komersial ditambah $1 \%$ tepung kulit kerang. C : Ransum komersial ditambah $2 \%$ tepung kulit kerang. D : Ransum komersial ditambah 3\% tepung kulit kerang.

\section{Pengacakan ayam}

Prosedur pengacakan ayam dilakukan dalam penelitian ini yaitu, diambil 100 ekor ayam yang umurnya sama, ditimbang dan dicari berat rata-ratanya. Ayam yang digunakan di dalam penelitian ini adalah ayam yang masuk dalam berat rata-rata 1998,85g \pm 5 ,18 g, ayam dipilih dan ditempatkan dalam kandang penelitian yang telah tersedia. Setiap 1 petak kandang diisi 1 ekor ayam, dimana secara keseluruhan menggunakan 100 ekor ayam dan 100 unit petak kandang. 


\section{Pencampuran bahan ransum}

Pencampuran ransum dilakukan dengan cara menimbang masing-masing bahan penyusun ransum sesuai dengan kebutuhan. Penimbangan dimulai dari bahan yang paling banyak, diikuti dengan bahan yang lebih sedikit. Ransum yang telah jadi, dimasukkan kedalam kantong plastik yang diberi label sesuai dengan perlakuan.

\section{Pemberian ransum dan air minum}

Pemberian ransum dan air minum diberikan secara ad libitum selama penelitian. Ransum diberikan setiap pagi yaitu pukul 08.00 WITA dan dilakukan pengecekan setiap saat untuk memastikan pakan masih tersedia pada tempat pakan yang sudah disediakan. Air minum yang diberikan selama penelitian bersumber dari perusahaan air minum (PDAM) ditempat

\section{Variabel yang Diamati}

1. Konsumsi Ransum Perhari

Konsumsi ransum adalah jumlah ramsum yang dikonsumsi selama penelitian. Dihitung dengan mengurangi jumlah ransum yang diberikan dengan ransum sisa.

Konsumsi Ransum Perhari = Ransum yang diberikan - ransum sisa

2. Produksi Telur Harian (hand day production).

Produksi telur harian adalah jumlah telur yang dihasilkan oleh ayam setiap hari dihitung selama penelitian.

Persentase produksi telur dihitung dengan rumus berikut :

$$
\text { hand day production }=\frac{\text { produksi telur perhari }}{\text { jumlah ayam }} \times 100 \%
$$

3. Bobot Telur

Bobot telur adalah rata-rata bobot telur yang dihasilkan ayam selama penelitian.

\section{Feed Convertion Ratio (FCR)}

Feed Convertion Ratio dihitung dengan membagi konsumsi ransum selama penelitian dengan bobot telur yang diperoleh selama penelitian.

$$
F C R=\frac{\text { konsumsi ransum }}{\text { bobot telur total }}
$$




\section{HASIL DAN PEMBAHASAN}

Hasil penelitian dari pengaruh ayam yang diberikan ransum komersial dengan tambahan tepung kulit kerang 1\%,2\%, dan 3\% terhadap konsumsi ransum, produksi telur harian, bobot telur, dan Feed Convertion Ratio (FCR) dapat dilihat pada tabel dibawah.

Tabel 3. Produksi Telur Ayam ISA Brown Pada Umur 95 Minggu yang Diberikan Ransum Komersial Ditambah Tepung Kulit Kerang sebagai Sumber Kalsium selama Penelitian.

\begin{tabular}{|c|c|c|c|c|c|}
\hline \multirow[t]{2}{*}{ VARIABEL } & \multicolumn{4}{|c|}{ PERLAKUAN $^{1}$} & \multirow[t]{2}{*}{ SEM $^{2}$} \\
\hline & $\mathrm{A}$ & B & $\mathrm{C}$ & $\mathrm{D}$ & \\
\hline $\begin{array}{l}\text { Konsumsi ransum } \\
\text { (g/ekor) }\end{array}$ & $3293,89^{\mathrm{a} 3}$ & $3296,19^{a}$ & $3270,40^{\mathrm{a}}$ & $3272,80^{\mathrm{a}}$ & 0,50 \\
\hline $\begin{array}{l}\text { Produksi telur } \\
\text { harian }(\%)\end{array}$ & $61,14^{\mathrm{a}}$ & $62,86^{\mathrm{a}}$ & $63,43^{\mathrm{a}}$ & $65,38^{a}$ & 1,65 \\
\hline $\begin{array}{l}\text { Bobot telur } \\
\text { (g) }\end{array}$ & $1076,63^{b}$ & $1111,77^{\mathrm{ab}}$ & $1122,46^{\mathrm{a}}$ & $1145,88^{\mathrm{a}}$ & 0,20 \\
\hline FCR & $3,06^{\mathrm{a}}$ & $2,97^{\mathrm{a}}$ & $2,91^{\mathrm{a}}$ & $2,85^{\mathrm{a}}$ & 0,09 \\
\hline
\end{tabular}

Keterangan :

1. A : Ransum komersial tanpa tambahan tepung kulit kerang

B : Ransum komersial dan $1 \%$ tepung kulit kerang.

$\mathrm{C}$ : Ransum komersial dan $2 \%$ tepung kulit kerang.

D : Ransum komersial dan 3\% tepung kulit kerang.

2. SEM : "Standard Error of the Treatment Means"

3. Superskrip yang sama pada baris yang sama tidak berbeda nyata $(\mathrm{P}>0,05)$

\section{Konsumsi ransum}

Hasil penelitian menunjukkan bahwa rataan konsumsi ransum pada ayam yang diberikan ransum komersial tanpa tambahan tepung kulit kerang sebagai kontrol (A) adalah 117,693 g/ekor (Tabel 4.1). Rataan konsumsi pakan pada ayam yang diberi tambahan tepung kulit kerang $1 \%$ pada ransum komersial (B) adalah 0,02\% lebih tinggi dari perlakuan A dan secara statistik berbeda tidak nyata $(\mathrm{P}>0,05)$. Sedangkan pada ayam yang diberi tambahan $2 \%$ tepung kulit kerang pada ransum komersial (C) dan 3\% tepung kulit kerang pada ransum komersial (D) masing-masing dan 0,76\%, 0,69\% lebih rendah dibandingkan dengan perlakuan A dan secara statistik berbeda tidak nyata $(\mathrm{P}>0,05)$.

Hasil penelitian menunjukkan konsumsi ransum perlakuan B lebih tinggi dari A dan perlakuan C, D lebih rendah dari perlakuan A secara statistik mendapatkan hasil berbeda tidak nyata $(\mathrm{P}>0,05)($ Gambar 1$)$. 


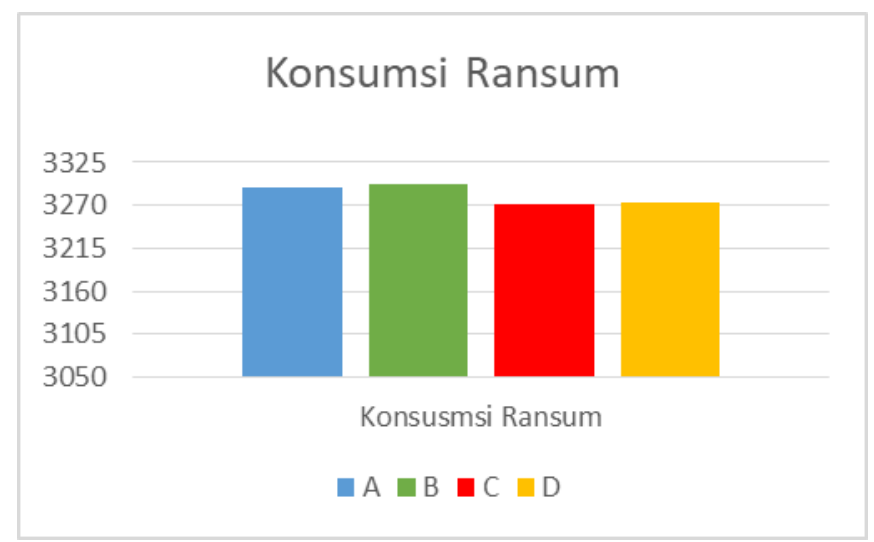

\section{Gambar 1. Grafik konsumsi ransum ayam ISA Brown yang diberikan pakan komersil ditambah tepung kulit kerang dalam jumlah yang berbeda selama penelitian.}

Pengaruh yang tidak nyata tersebut disebabkan karena ayam yang mendapat pakan dengan kandungan nutrisi yang sama dengan kandungan energi pakan yang sama. Ayam yang telah berumur 95 minggu juga menjadi penyebab sudah tidak adanya laju pertumbuhan sehingga tidak ada perbedaan yang signifikan dalam hal konsumsi ransum. Hal ini sesuai dengan pendapat Wahju, (2004) bahwa Konsumsi ayam petelur dipengaruhi oleh suhu lingkungan, bangsa, umur, jenis kelamin, imbangan zat makanan dalam ransum, kecepatan pertumbuhan, tingkat produksi, bobot badan, palatabilitas dan tingkat energi metabolisme ransum, semakin tinggi energi dalam ransum maka konsumsi ransum akan menurun begitu pula sebaliknya. Konsumsi ransum menjadi salah satu hal terpenting yang dapat mempengaruhi produksi telur. Hal senada juga dijelaskan dalam (NRC, 1994) bahwa faktor yang mempengaruhi konsumsi ransum antara lain besar tubuh ayam, aktifitas sehari-hari, suhu lingkungan, kualitas dan kuantitas ransum. Tinggi rendahnya tingkat konsumsi ransum juga disebabkan adanya perbedaaan kondisi lingkungan, status kesehatan ayam dan ransum (Utomo, 2017).

\section{Produksi Telur Harian (hand day production)}

Hasil penelitian menunjukkan bahwa rataan produksi telur harian pada ayam yang diberikan ransum komersial tanpa tambahan tepung kulit kerang sebagai kontrol (A) adalah 61,14\% (Tabel 4.1). Rataan produksi telur harian pada ayam yang diberi tambahan tepung kulit kerang $1 \%$ pada ransum komersial (B), 2\% tepung kulit kerang pada ransum komersial (C), 3\% tepung kulit kerang pada ransum komersial (D) masing-masing adalah 2,73\%, 3,61\%, 
6,14\% lebih tinggi dibandingkan dengan perlakuan A dan secara statistik berbeda tidak nyata $(\mathrm{P}>0,05)$.

Rataan produksi telur harian (hen day production) meningkat sebesar masing- masing adalah 2,73\%, 3,61\%, 6,14\% dibandingkan dengan perlakuan A pada perlakuan B, C, D, secara statistik menunjukkan hasil berbeda tidak nyata (P>0,05) (Gambar 2).

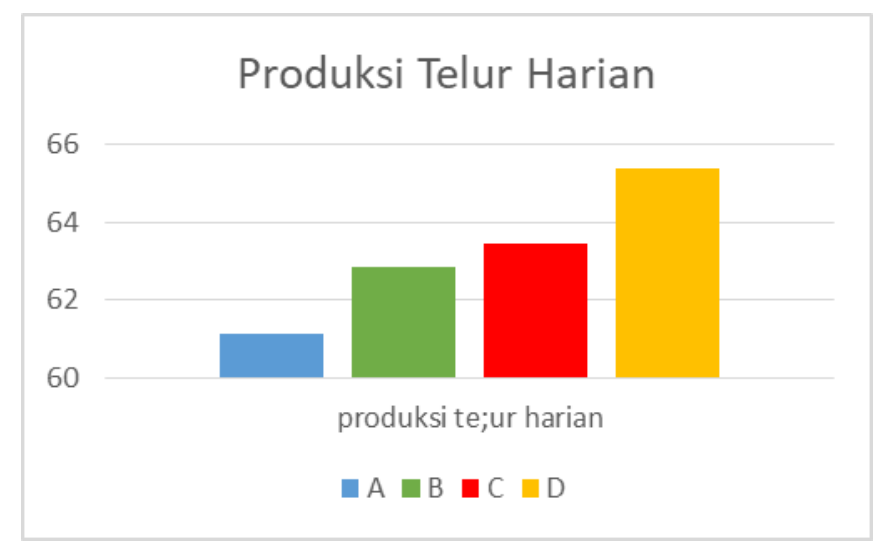

\section{Gambar 2. Grafik produksi telur harian (hen day production) ayam ISA Brown yang diberikan pakan komersil ditambah tepung kulit kerang dalam jumlah yang berbeda.}

Pemberian tambahan kalsium tepung kulit kerang pada ransum tidak memberikan perbedaan yang signifikan terhadap produksi telur karena ayam sudah berumur 95 minggu, walaupun pengaruhnya tidak signifikan tetapi ada kecenderungan mengalami peningkatan. Hal ini terlihat bahwa perlakuan $\mathrm{B}, \mathrm{C}$, dan $\mathrm{D}$ memberikan produksi telur yang lebih tinggi dibandingkan A. Fungsi utama kalsium adalah membentuk serta memperkuat kerabang telur dan membantu sistem kerja gizzard sehingga saluran pencernaan dan saluran reproduksi ayam menjadi lebih sehat dan dapat bekerja dengan baik. Menurut Setiawati et al. (2016), hen day production yang tinggi umumnya diiringi dengan pemberian pakan yang mencukupi kebutuhan hidup pokok dan produksi telur. Hal senada disampaikan oleh Tilman et al. (1998), bahwa jumlah ransum yang dikonsumsi oleh ternak digunakan untuk mencukupi hidup pokok dan untuk produksi ternak tersebut. Utomo (2017), menambahkan bahwa perbedaan tinggi rendahnya produksi telur ayam ras dipengaruhi beberapa faktor, antara lain; genetik, kualitas dan kuantitas ransum yang diberikan, dan kesehatan ternak.

\section{Bobot Telur}

Hasil penelitian menunjukkan bahwa rataan bobot telur pada ayam yang diberikan ransum komersial tanpa tambahan tepung kulit kerang sebagai kontrol (A) adalah 62,89 gram 
(Tabel 4.1). Rataan bobot telur yang diberi tambahan tepung kulit kerang $1 \%$ pada ransum komersial (B) adalah 0,44\% lebih tinggi dibanding dengan perlakuan A, tetapi secara statistik berbeda tidak nyata $(\mathrm{P}>0,05)$. Sedangkan bobot telur ayam yang diberi tambahan tepung kulit kerang 2\% pada ransum komersial (C) dan 3\% tepung kulit kerang pada ransum komersial (D) masing-masing adalah 0,49\%, 0,78\% lebih tinggi dibandingkan dengan perlakuan A dan secara statistik berbeda nyata $(\mathrm{P}<0,05)$.

Dari hasil penelitian menunjukkan bahwa perlakuan B, C dan D memiliki rataan bobot telur masing-masing 0,44\%,0,49\%,0,78\% lebih tinggi dibandingkan A, tetapi secara statistik menunjukkan hasil berbeda nyata $(\mathrm{P}<0,05)($ Gambar 3). Bobot telur perlakuan B tidak nyata lebih tinggi dibandingkan dengan perlakuan A, sedangkan perlakuan $\mathrm{C}$ dan D nyata memiliki bobot telur yang lebih tinggi dari A.

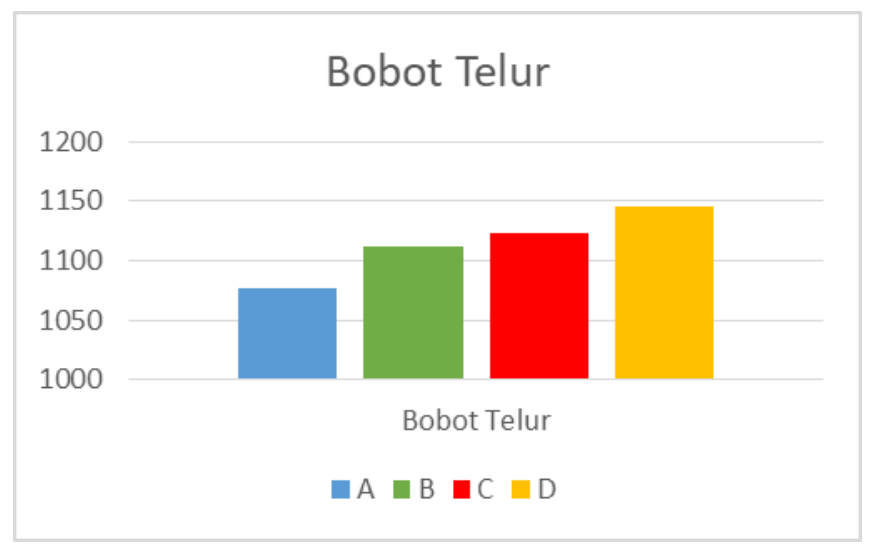

\section{Gambar 3. Grafik bobot telur ayam ISA Brown yang diberikan pakan komersil ditambah tepung kulit kerang dalam jumlah yang berbeda.}

Hal ini disebabkan karena jumlah kalsium yang ditambahkan dalam perlakuan B belum mampu meningkatkan ketebalan cangkang telur yang secara signifikan memberikan pengaruh terhadap bobot telur. Pengaruh kalsium dari kulit kerang terbukti signifikan meningkatkan bobot telur ayam karena ayam mendapatkan tambahan kalsium. Bobot telur yang berbeda juga disebabkan oleh salah satunya adalah dari jumlah kalsium yang cukup. Kalsium yang cukup akan menjamin bahwa kerabang telur akan terbentuk dengan sempurna terutama dari ketebalannya. Ketebalan kerabang telur juga memiliki pengaruh terhadap berat telur. (Heppi et alI., 2019) Berat telur yang tidak berbeda disebabkan oleh jenis dan umur ayam sama, selain itu ayam Isa Brown yang digunakan mempunyai berat badan homogen sehingga berat telur yang dihasilkan tidak jauh berbeda serta jenis ransum komersial yang digunakan sama dan didukung dengan adanya nilai FCR yang sama sehingga pasokan nutrisi yang didapatkan ternak relatif sama mengakibatkan berat telur yang dihasilkan tidak jauh 
berbeda. Hal ini sejalan dengan penelitian (Sumayani et al., 2019) yang menyatakan berat telur di pengaruhi oleh kualitas bagian dalam telur yang lebih cenderung mengikuti pola pertambahan berat telur, semakin meningkat berat telur semakin meningkat pula bagianbagian dalam telur, hal ini di pengaruhi oleh zat nutrisi yang terkadung dalam ransum dan kesehatan. Anggorodi (1995) menambahkan bahwa besarnya telur dipengaruhi oleh beberapa faktor termasuk sifat genetik, tingkat dewasa kelamin, umur, dan ransum sehari-hari. Penambahan kalsium pada ayam sedang bertelur dapat meningkatkan bobot telur. Wahju (2004) bahwa untuk pembentukan kerabang telur ayam membutuhkan lebih dari 4 grm kalsium perhari. Faktor penambahan kalsium memperlihatkan pemberian kalsium sesuai kebutuhan ayam petelur dapat menghasilkan bobot optimal (Nakajima, 1990).

\section{Feed Convertion Ratio (FCR)}

Hasil penelitian menunjukkan bahwa rataan FCR pada ayam yang diberikan ransum komersial tanpa tambahan tepung kulit kerang sebagai kontrol (A) adalah 3,06973 (Tabel 4.1). Rataan FCR pada ayam yang diberi tambahan tepung kulit kerang $1 \%$ pada ransum komersial (B), 2\% tepung kulit kerang pada ransum komersial (C), 3\% tepung kulit kerang pada ransum komersial (D) masing-masing adalah 3,16\%, 4,99\%, 6,91\% lebih rendah dibandingkan dengan perlakuan A dan secara statistik berbeda tidak nyata $(\mathrm{P}>0,05)$.

FCR perlakuan B, C, dan D memiliki rataan nilai FCR lebih rendah dibandingkan A, tetapi secara statistik menunjukkan hasil tidak berbeda nyata $(\mathrm{P}<0,05)($ Gambar 4).

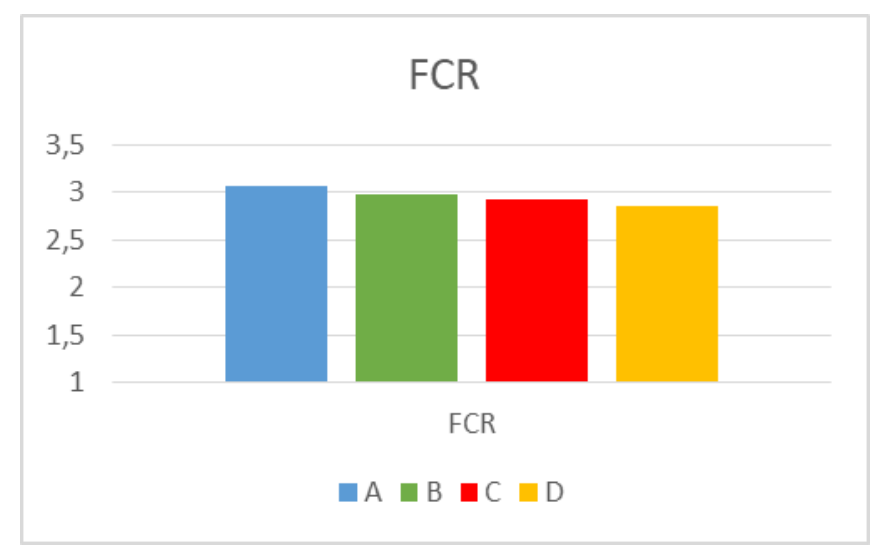

\section{Gambar 4. Grafik Feed convertion ratio (FCR) ayam ISA Brown yang diberikan ransum komersil ditambah tepung kerang dalam jumlah yang berbeda.}

Hasil FCR tersebut disebabkan oleh berat telur yang dihasilkan selama penelitian relatif sama, selain itu umur dan jenis ternak serta ransum komersial yang digunakan sama sehingga nilai FCR yang didapat tidak jauh berbeda. Nilai FCR yang didapatkan pada 
penelitian ini berkisar antara 2,85-3,06. Nilai FCR ini menandakan efisiensi penggunaan ransum yang tinggi, sehingga ransum yang didapatkan oleh ayam telah mampu memenuhi kebutuhan nutrisinya selain untuk pertumbuhan tetapi juga dalam memproduksi sejumlah telur. Menurut Nuraini et al. (2015) bahwa konsumsi yang tinggi harus diimbangi dengan produksi yang tinggi, apabila konsumsi tinggi tetapi produksi rendah maka akan diperoleh nilai konversi yang buruk, sehingga akan menimbulkan kerugian pada peternak. Nilai konversi ransum yang didapatkan pada penelitian ini masih berada pada standar konversi ransum yaitu 2,4-2,5 (Hendrix, 2007). Rasyaf (1994) berpendapat bahwa semakin kecil konversi ransum berarti pemberian ransum semakin efisien, namun jika konversi ransum tersebut membesar, maka telah terjadi pemborosan. Menurut Anggorodi (1995) konversi ransum dipengaruhi beberapa faktor seperti umur ternak, bangsa, kandungan gizi ransum, keadaan temperatur dan keadaan ternak, tatalaksana dan penggunaan bibit yang baik. Lacy dan Vest (2000), menyatakan beberapa faktor utama yang mempengaruhi konversi ransum adalah genetik, kualitas ransum, penyakit, temperatur, sanitasi kandang, ventilasi, pengobatan, dan manajemen kandang, bentuk fisik ransum dan komposisi nutrisi ransum.

\section{SIMPULAN DAN SARAN}

\section{Simpulan}

Berdasarkan hasil penelitian ini dapat disimpulkan bahwa pemberian ransum komersial dengan penambahan 2\%, dan 3\% tepung kulit kerang sebagai sumber kalsium dapat meningkatkan bobot telur tetapi tidak memberikan hasil yang diharapkan terhadap produksi telur harian (hen day production), FCR, dan konsumsi ransum ayam ISA Brown umur 95 minggu .

\section{Saran}

Berdasarkan hasil penelitian ini dapat disarankan kepada peternak, khususnya peternak ayam petelur bahwa penambahan kalsium tepung kulit kerang sebanyak $2 \%$ dan $3 \%$ pada ransum komersial mampu meningkatkan bobot telur yang lebih tinggi.

\section{UCAPAN TERIMAKASIH}

Penulis mengucap syukur kepada Ida Sang Hyang Widhi Wasa sehingga penulis diberi kelancaran, kekuatan, dimampukan dalam melaksanakan penelitian ini. Penulis 
mengucapkan banyak terimakasih kepada Rektor Universitas Udayana Prof. Dr. dr. A.A. Raka Sudewi, Sp.S (K)., Dekan Fakultas Peternakan Universitas Udayana Bapak Dr. Ir. I Nyoman Tirta Ariana, MS., orang tua, serta teman-teman seperjuangan.

\section{DAFTAR PUSTAKA}

Anggorodi, R. 1995. Ilmu Makanan Ternak Umum. PT Gramedia. Jakarta.

Bumi, Merdeka. 2010. Sukses Peternak Ayam Ras Petelur. Atma Media Press. Yogyakarta

Dewi, G. A. M. K. 2010. Pengaruh kalsium-asam lemak sawit (Ca-ALS) dan kalsium terhadap bobot telur, tebak kerabang dan kekuatan kerabang ayam petelur lohman. MIP. 13(1):20-35

Farmer, M., D.A. Roland, Sr and M.K Eckman. 1983. Calcium metabolism in broiler breeder hens. 2. The influence of the time feeding on calcium status of the digestive systemand eggshell quality in broiler breeders. Poult. Sci. 62: 465-471.

Hendrix. 2007. Product Performance. ISA-Hendrix Genetics Company. http://www.hendrix genetics.com

Heppi. N. W. A. L., G. A. M. K. Dewi, dan I. K. A. Wiyana. 2019. Produksi Telur Ayam Isa Brown Pasca Vaksinasi dengan Kandidat Vaksin Egg Drop Syndrome (EDS) Diberi Jumlah Ransum yang Berbeda. Peternakan Tropika Vol. 7 No. 2 Th. 2019: 507- 521

Highfill, C. 1998. Calcium, Phosphorus and Vitamin D3 in Your Bird's Diet. Article II. Winged Wisdom. Pet Bird Magazine.

Lacy, M. dan Vest, L.R. 2000. Improving feed conversion in broiler: a guide for growers.http://www.ces.uga.edu/pubed/c:793-W.html.

Nakajima, 1990. Re-Evaluasi of calcium and phosphorus requirement of laying hens foroptimum performance and egg shell quality.

National Research Council. 1994. Nutrient Requirements of Poultry. Ed Rev ke-9. Washington DC: Academy Pr.

North, M. O. and D. D. Bell. 1990. Commercial Chicken Production Manual. 4thEdition. Van Nostrand Rainhold. New York.

Nuraini, A., Djulardi dan M. E. Mahata. 2015. Pakan non konvensional fermentasi dengan Phanerochaete chrysosporium dan Neurospora crassa untuk memproduksi telur rendah kolesterol. Laporan Penelitian. Hibah Kompetensi Dikti. Lembaga Penelitian dan Pengabdian Masyarakat Universitas Andalas. Padang.

Setiawati. T, Afnan. R, Ulupi. N. 2016. Performa produksi dan kualitas telur ayam petelur pada sistem litter dan cage dengan suhu kandang berbeda. Jurnal IImu Produksi dan Teknologi Hasil Peternakan .ISSN 2303-2227. Vol. 04 No. 1 Januari 2016 HIm: 197203.

Sumayani, N. K. E., G. A. M. K. Dewi, dan G. A.Y. Kencana. Kualitas Telur Ayam ISA Brown Umur 18-22 Minggu Pasca Divaksinasi Egg Drop Syndrome dan Diberi Ransum Dalam Jumlah yang Berbeda. Peternakan Tropika Vol. 7 No. 1 Th. 2019: 169 - 184 
Tillman, A.D., H. Hartadi, S. Reksohadiprojo, S. Prawirokusumo. dan S. Lebdosoekojo. 1998. Ilmu Makanan Ternak Dasar. Edisi Keenam. Gadjah Mada University Press. Yogyakarta.

Utomo, D.M. 2017. Performa ayam ras petelur coklat dengan frekuensi pemberian ransum yang berbeda. Jurnal Aves Vol 11 (2): 23-37, Desember 2017, Jurusan Ilmu Ternak, Fakultas Peternakan, Universitas Islam Balitar

Wahju, J. 2004. Ilmu Nutrisi Unggas. Gadjah Mada University Press Yogyakarta. 